\title{
A SURVEY ON THE INCIDENCE OF LEPTOSPIROSIS IN DOGS FROM THE URBAN COMMUNITY AT CURITIBA URBAN REGION
}

\author{
BACILA , Ma. ${ }^{1}$; ANDRADE, U.V.C. ${ }^{2}$; VILLANOVA JR, J.A. ${ }^{3}$; SASAKI, A.Y. ${ }^{4}$; \\ STENCELL, R. ${ }^{4}$; BACILA, M. ${ }^{1}$ \\ ${ }^{1}$ Pontifícia Universidade Católica do Paraná; \\ ${ }^{2}$ Mestrando do Curso de Pós-Graduação em Ciências Veterinárias - UFPR; \\ ${ }^{3}$ Pesquisador; \\ ${ }^{4}$ Graduandos de Medicina Veterinária da PUC PR, Pesquisadores do PIBIC/PUCPR; \\ Leptospirosis is an infectious disease caused by Leptospira ictherohaemorragiae. \\ Transmitted by the urine of the sewer rat, Rattus rattus norvegicus (Berkenhout), \\ leptospirosis occurs in our Country either in isolated way or in seasonal epidemic \\ outbreaks. Being a cosmopolitan disease, leptospirosis may occur either in urban or \\ in rural areas, displaying several symptoms as fever, hemorrhage, jaundice and \\ uremia with high degrees of lethality caused by liver and renal insufficiencies. The \\ present research work was undertaken in order to analyze the canine population \\ from the Curitiba urban community of Vila das Torres, considering the dog possible \\ epidemiological role as bearer and potential transmitter of leptospirosis. A total of \\ 178 of blood samples were collected during the years of $1997(n=82)$ and $2000(n=$ \\ 96) from dogs living at Vila das Torres. By means of microscopic serum \\ agglutination, $32.9 \%$ of the blood samples collected during 1997 and $31.25 \%$ of the \\ ones collected during 2000 showed to be reactive mainly towards the Canicola, \\ Copenhageni, Icterohaemorrhagiae and Grippotyphosa among 23 sorovares studied. \\ displaying titles from $1 / 200$ in blood samples from the year 2000 up to $1 / 600$ in blood \\ samples from the year 1997. According to these results, it has to be consider the fact \\ that the population from the Community of Vila das Torres is living in a possible \\ situation of epidemic risk by being in cohabitation with leptospirosis bearing dogs, \\ certainly a combination of factors that favors an outbreak of this infectious disease.
}

Key Word: leptospirosis, sorovar, Rattus rattus norvegicus. 